Original Research Article

\title{
Effect of aceclofenac on pharmacokinetics of phenytoin sodium in epileptic patients
}

\author{
Rushikesh S. Kulkarni ${ }^{1 *}$, Kantilal C. Chandaliya ${ }^{2}$
}

${ }^{1}$ Department of Pharmacology, Swami Ramanand Teerth Government Rural Medical College, Ambajogai,

Maharashtra, India

${ }^{2}$ Department of Pharmacology, Government Medical College, Aurangabad, Maharashtra, India

Received: 06 August 2018 Accepted: 31 August 2018

\section{*Correspondence to:}

Dr. Rushikesh S. Kulkarni, Email: rushikeshk3@gmail.com

Copyright: (C) the author(s), publisher and licensee Medip Academy. This is an openaccess article distributed under the terms of the Creative Commons Attribution NonCommercial License, which permits unrestricted noncommercial use, distribution, and reproduction in any medium, provided the original work is properly cited.

\begin{abstract}
Background: Epilepsy is a chronic disorder characterised by recurrent seizures/convulsions that affects people of all ages. Phenytoin sodium is an effective, cheaper, most commonly used first line drug for the treatment of epilepsy. As a result of sure encounter with various painful inflammatory conditions like chronic arthritis at some point of time the co administration of analgesics becomes inevitable in epileptic patients. Aceclofenac is a commonly prescribed, moderately COX-2 selective congener of Diclofenac. Because of similarity in some pharmacokinetic properties between Phenytoin sodium and Aceclofenac; the possibility of drug interaction between them is postulated.

Methods: In this prospective randomized observational study diagnosed and stabilized patients of epilepsy of either sex of more than 18 years of age were included. Patient taking Phenytoin sodium 100mg BD and prescribed tab Aceclofenac $100 \mathrm{mg}$ bd for 7 days. Serum Phenytoin sodium levels were measured before and after administering Aceclofenac. Graph pad Prism software Version 6 used for statistical analysis.

Results: At the end of the study, we found statistically significant effect ( $\mathrm{p}=$ 0.0104) on serum Phenytoin sodium level. However, no statistical difference was found in any of the other parameters i.e., epilepsy outcome parameters and lab parameters - Urine routine microscopy, CBC, LFT, KFT and RBG.

Conclusions: Findings in this study forms a platform for future researchers to explore this field of research by designing an interventional study with well scrutinised study population considering all pharmacokinetic parameters.
\end{abstract}

Keywords: Aceclofenac, Phenytoin sodium, Pharmacokinetics

\section{INTRODUCTION}

Epilepsy is a chronic disorder characterised by recurrent seizures/convulsions that affects people of all ages (Around 5.5 million in India). ${ }^{1,2}$ Though variety of newer drugs are available for the management of epilepsy Phenytoin sodium is an effective, cheaper, most commonly used first line drug for the treatment of epilepsy. Even at a tertiary care hospital around 80 to $90 \%$ epileptic patients were stabilised with the drug Phenytoin sodium with proper doses. ${ }^{3,4}$ It has narrow therapeutic index and its bioavailability varies with variety of formulations, drug interactions, inter individual variations of drug metabolism and protein binding. ${ }^{3,5}$

Aceclofenac is a commonly prescribed, moderately COX2 selective congener of Diclofenac. ${ }^{6}$ It has chondroprotective properties due to increased synthesis of proteoglycans and hyaluronon molecules in cartilage matrix. It is having good efficacy, safety and tolerability for different pain conditions. It is a routinely prescribed drug. ${ }^{7-9}$

The possibility of drug interactions between Phenytoin sodium and Aceclofenac can be postulated based on some common properties. Both drugs are acidic in nature and 
can interact at absorption and displacement from protein binding sites. Moreover, both are substrate for Cyp2C9 enzyme thus enzyme induction or inhibition can account for drug interaction. ${ }^{6,10-13}$

A papallel study in Rabbits by Medhi et al, proved significant decrease in Phenytoin sodium level due to increased displacement and metabolism with Aceclofenac. ${ }^{14}$

So far, no human study has been conducted to evaluate drug interaction of Phenytoin sodium with Aceclofenac. In the view of above background, the present study is planned to see any changes in therapeutic drug concentration of Phenytoin sodium when it is co-prescribed with Aceclofenac.

\section{METHODS}

The Prospective Randomized Observational study was conducted in department of Pharmacology in collaboration with department of Medicine at GMCH Aurangabad during 2015 to 2017 . Objectives of the study were to study any change in serum level concentration of Phenytoin sodium when Aceclofenac is co-administered with it and to evaluate effect on Epilepsy outcome. Diagnosed and stabilized patients of epilepsy of either sex of more than 18 years age receiving Phenytoin sodium 100mg BD and coprescribed with tablet Aceclofenac 100mg BD willing to give informed written consent were included in the study. While patient with known history of chronic hepatic or renal disease, pregnant patient, history of any hypersensitivity reaction to above drugs, not willing to give informed consent and not willing to follow up were excluded from the study.

Random number table using research randomiser software version 4.0 was generated for patient selection. Informed consent was obtained in local language. Study started with sample size 50 considering feasibility in institutional set up. With progress of study data generated from initial 10 subjects were considered as internal pilot. ${ }^{15}$ Sample size was calculated with confidence interval $95 \%$ and power $80 \%$ using following formula.

$N=\left(z_{\overline{2}}+z_{\beta}\right)^{2} \times\left(\frac{S(\Delta)}{\text { Effect size }}\right)^{2}$

Where;

$\mathrm{N}$ - Sample size,

$Z_{\alpha / 2}, Z_{\beta}$ - Standard normal deviate for $\alpha / 2$ and $\beta$ respectively,

$\mathrm{S}(\Delta)$ - Standard deviation of the change in the outcome,

Effect size - Difference between 2 means

With this formula we got $\mathrm{N}=37.1$. Considering drop outs we continued study with sample size 50 .
The study parameters were assessed on day 0 with Tab Phenytoin sodium only and on day 7 after receiving Tab Phenytoin sodium along with Tab Aceclofenac by using Graph pad Prism software Version 6 (Figure 1). Pharmacokinetic outcome was assessed by measuring serum Phenytoin sodium level using RECIPE ClinRep® Complete Kit. ${ }^{16}$ HPLC conditions were as - Pump: isocratic pump, flow rate: $1.0 \mathrm{ml} / \mathrm{min}$, Injection volume: 10 $\mu 1$, Injection interval: $15 \mathrm{~min}$, UV/VIS-Detector: $205 \mathrm{~nm}$, HPLC-Thermostat: $55^{\circ} \mathrm{C}$. For epilepsy outcome seizure frequency, development of any study drug associated toxicity features and any significant clinical remarks were noted. Other Routine Lab Parameters like urine routine microscopy, complete blood count (CBC) including haemoglobin $\%$, total leucocyte count (TLC), differential leucocyte count (DLC), platelet count, liver function test (LFT) including serum Albumin, Sr Bilirubin, SGOT, SGPT, kidney function test (KFT) including urea and creatinine blood sugar (glucose) level (random) were measured.

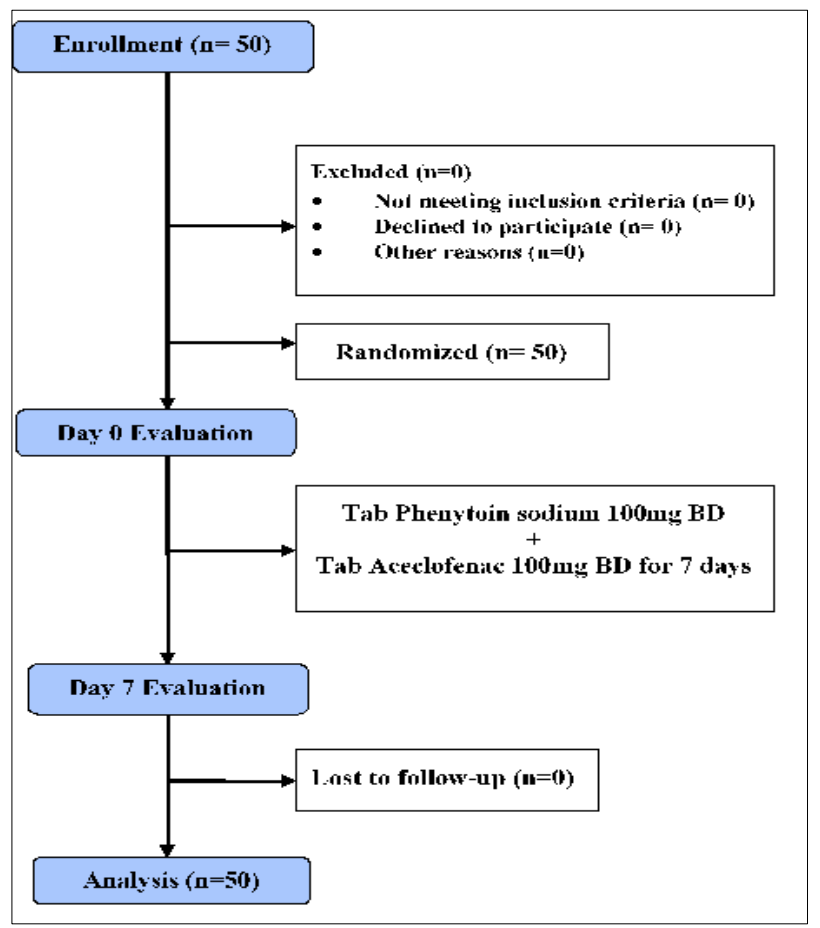

Figure 1: Study flowchart.

\section{RESULTS}

A total of 50 eligible patients fulfilling the inclusion criteria were randomly selected. The study parameters were assessed on day 0 with Tab Phenytoin sodium only and on day 7 after receiving Tab Phenytoin sodium along with Tab Aceclofenac. The statistical assessment was done by applying paired t test to obtained quantitative data. For qualitative nominal data like change in seizure frequency, development of any study drug associated toxicity features simple descriptive statistics was used to generate frequencies, percentages and proportions. 


\section{Parameter for assessment of effect on pharmacokinetics}

Assessment of Phenytoin sodium pharmacokinetic was done by measuring serum Phenytoin sodium level on day 0 with Phenytoin sodium only and then on day 7 with Aceclofenac. On day 0, the mean Phenytoin sodium level with Tab Phenytoin sodium alone was 15.03 \pm 0.9521 $\mathrm{mg} / \mathrm{L}$. On day 7, with Tab Phenytoin sodium + Tab Aceclofenac the mean Phenytoin sodium level was reduced to $14.57 \pm 1.0807 \mathrm{mg} / \mathrm{L}$. Same is illustrated graphically in Figure 2. The reduction in the mean Phenytoin sodium level with Aceclofenac on day 7 was statistically significant with $\mathrm{p}$ value of $0.0104(\mathrm{p}<0.05)$ (Table 1). Test of significance used was paired $t$ test.

Table 1: Effect on phenytoin sodium level.

\begin{tabular}{|lll|}
\hline Phenytoin sodium Level in mg/L & 'P' value \\
\hline Day 0 & Day 7 & \\
\hline $15.03 \pm 0.9521$ & $14.57 \pm 1.0807$ & 0.0104 \\
\hline
\end{tabular}

\begin{tabular}{|c|c|c|c|}
\hline \multirow{10}{*}{ 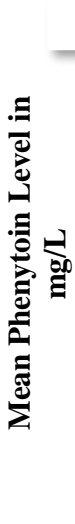 } & \multicolumn{2}{|c|}{ 口Day 0} & ⿴囗口) 7 \\
\hline & 15.1 & 15.03 & \\
\hline & 15 & & \\
\hline & 14.9 & & \\
\hline & 14.8 & & \\
\hline & 14.7 & & \\
\hline & 14.6 & & 14.57 \\
\hline & 14.5 & & \\
\hline & 14.4 & & \\
\hline & & Day 0 & Day 7 \\
\hline
\end{tabular}

Figure 2: Mean Phenytoin sodium level at day 0 and day 7.

\section{Parameters for assessment of effect on epilepsy outcome}

For epilepsy outcome seizure frequency, development of any study drug associated toxicity features and any significant clinical remarks were noted. As shown in Table 2 out of total 50 subjects no subject has shown change in seizure frequency or any toxicity features after 7 days with Aceclofenac.

Table 2: Epilepsy outcome parameters.

\begin{tabular}{|llll|}
\hline Parameter & $\begin{array}{l}\text { Frequency } \\
\text { of subjects } \\
\text { with } \\
\text { positive } \\
\text { response }\end{array}$ & $\begin{array}{l}\text { Frequency } \\
\text { of subjects } \\
\text { with } \\
\text { negative } \\
\text { response }\end{array}$ & $\begin{array}{l}\text { Total } \\
\text { subjects } \\
\text { assessed }\end{array}$ \\
\hline $\begin{array}{l}\text { Change in } \\
\text { seizure } \\
\text { frequency }\end{array}$ & Nil & 50 & 50 \\
\hline $\begin{array}{l}\text { Development of } \\
\text { any study drug } \\
\text { associated } \\
\text { toxicity features }\end{array}$ & Nil & 50 & 50 \\
\hline $\begin{array}{l}\text { Any significant } \\
\text { clinical remarks }\end{array}$ & Nil & 50 & 50 \\
\hline
\end{tabular}

\section{Other routine laboratory parameters}

Other lab parameters assessed were complete blood count (CBC) including haemoglobin \%, total leucocyte count (TLC), differential leucocyte count (DLC), platelet count, liver function test (LFT) including serum Albumin, serum Bilirubin, SGOT, SGPT, kidney function test (KFT) including urea and creatinine and random blood glucose level. As shown in Table 3 none of these parameters were statistically significant as p values were greater than 0.05 .

Table 3: Routine lab parameters.

\begin{tabular}{|llll|}
\hline Parameter & Day 0 & Day 7 & 'P' value \\
\hline Systolic Blood Pressure in $\mathrm{mmHg}$ & $127.1 \pm 8.172$ & $125.16 \pm 5.857$ & 0.1178 \\
\hline Diastolic Blood Pressure in $\mathrm{mmHg}$ & $82.64 \pm 3.713$ & $83.28 \pm 3.933$ & 0.4059 \\
\hline Hemoglobin in gm\% & $12.396 \pm 1.041$ & $12.766 \pm 0.991$ & 0.104 \\
\hline Platelet count *10 ${ }^{3} / \mathrm{mm}^{3}$ & $143.72 \pm 5.265$ & $143.94 \pm 5.776$ & 0.8378 \\
\hline Total Leucocyte count $/ \mathrm{mm}^{3}$ & $4761 \pm 82.386$ & $4709 \pm 177.29$ & 0.0683 \\
\hline Neutrophil \% & $59.04 \pm 4.58$ & $57.74 \pm 5.753$ & 0.1684 \\
\hline Lymphocyte \% & $32.86 \pm 4.54$ & $34.34 \pm 6.1$ & 0.1445 \\
\hline Monocyte \% & $5.12 \pm 1.043$ & $5.06 \pm 1.114$ & 0.7847 \\
\hline Eosinophil \% & $2.48 \pm 0.995$ & $2.42 \pm 0.971$ & 0.7828 \\
\hline Basophil \% & $0.5 \pm 0.505$ & $0.44 \pm 0.501$ & 0.5182 \\
\hline Blood Albumin Level in gm/dl & $3.808 \pm 0.349$ & $3.754 \pm 0.221$ & 0.3805 \\
\hline Serum Bilirubin Level in $\mathrm{mg} / \mathrm{dl}$ & $1.014 \pm 0.103$ & $0.96 \pm 0.178$ & 0.0573 \\
\hline SGOT in units/L & $25.06 \pm 3.431$ & $25.48 \pm 2.131$ & 0.4996 \\
\hline SGPT in units/L & $38.28 \pm 3.557$ & $37.86 \pm 1.702$ & 0.4441 \\
\hline Blood Urea level in $\mathrm{mg} / \mathrm{dl}$ & $5.028 \pm 1.059$ & $4.656 \pm 1.13$ & 0.1118 \\
\hline Serum Creatinine in $\mathrm{mg} / \mathrm{dl}$ & $0.908 \pm 0.114$ & $1.094 \pm 0.86$ & 0.1237 \\
\hline Blood Glucose in $\mathrm{mg} / \mathrm{dl}$ & $105.78 \pm 3.112$ & $105.66 \pm 2.752$ & 0.8227 \\
\hline
\end{tabular}




\section{DISCUSSION}

Significant reduction in mean Phenytoin sodium level can be either due to reduced bioavailability due to reduced absorption or accelerated elimination due to increased metabolism of Phenytoin sodium by Aceclofenac.

\section{Effect on absorption}

Both Aceclofenac and Phenytoin sodium are orally administered drugs. When two drugs are given orally there can be competition for transport processes involved in absorption. ${ }^{14}$

Work of Fromm D et al states that there operates multiple gastric mucosal defence mechanisms viz mucosal permeability to acid, active ion transport, blood flow, mucus secretion, epithelial restitution, and prostaglandin synthesis. NSAIDs causes mucosal damage by affecting these defences. ${ }^{17}$ In acidic environment Acidic drugs remain unionised and readily absorbed. ${ }^{18}$ Chronic gastritis, a common side effect of NSAIDs is associated with hypochlorhydria. ${ }^{19}$ Increase in gastric $\mathrm{pH}$ due to hypochlorhydria may decrease drug absorption of acidic drugs like Phenytoin sodium. Sigthorsson et al studied effect of long term NSAIDs on intestinal permeability. ${ }^{20}$ The present study results are in accordance to these findings.

Some researchers explored COX-1 sparring action Aceclofenac by comparing its gastrointestinal effects with other NSAIDs. Toru and Akira et al observed significantly less gastropathy and unchanged gastrodeodenal blood flow with Aceclofenac. $^{21}$ Hinz $\mathrm{B}$ et al, also proved gastrointestinal safety of Aceclofenac than other NSAIDs. ${ }^{22}$ This relative gastrointestinal safety causing relatively less effect on absorption of other drugs of Aceclofenac contradicts findings of present study.

\section{Protein displacement: a cause of rapid metabolism}

Sansom et al underlined significance of plasma protein displacement interactions in a restrictively cleared and highly protein bound $(90 \%)$ drug Phenytoin sodium. ${ }^{23}$ Comedication with other albumin binding acidic drugs is known to displace Phenytoin sodium from albumin. ${ }^{24}$ It was found that Aceclofenac is more than $99.7 \%$ bound to albumin. ${ }^{13}$ Work of Aronson et al described that plasma protein displacement of Phenytoin sodium causes transient increase in clinical effect because it results in a proportionately increased rate of metabolism of Phenytoin sodium. $^{25}$ In agreement to above research works the significant reduction in Phenytoin sodium level in this study may be attributed to plasma protein displacement.

\section{Enzyme induction: a possibility}

Though too early to comment our study postulates possibility of enzyme induction by Aceclofenac as a cause for significant reduction in serum Phenytoin sodium level.
According to Barry et al most of the NSAIDs are inhibitors of Phenytoin sodium metabolising enzymes. ${ }^{26}$ Although currently no direct evidence about enzyme inducing or enzyme inhibiting properties of Aceclofenac is available on Indexed literature; as a member of NSAIDs family it can be considered as an enzyme inhibitor. Postulates derived from current study contradicts to this school of thinking.

Throughout the duration of our study all the subjects have Phenytoin sodium levels maintained in the therapeutic range. Thus, absence of therapeutic failure and toxicity features in any one among the study subjects is justified.

This study has some noteworthy limitations like non interventional study design, no effective monitoring system to check patient compliance, no consideration of confounding factors in personal history (diet, smoking, alcohol consumption, any other substance use) and no assessment of other pharmacokinetic parameters.

\section{CONCLUSION}

In spite of shortcomings the findings of present study cannot be neglected. It forms a platform for future researchers to explore this field of research by designing an interventional study with well scrutinised study population considering all pharmacokinetic parameters. In light of findings of this study medical practitioners must become more vigilant while prescribing the drugs like Aceclofenac.

\section{ACKNOWLEDGEMENTS}

Authors would like to express their humble gratitude to the Department of Medicine for collaboration in the study hospital pharmacy for sharing the prescription copies and the Institution for their moral support to conduct the study.

Funding: No funding sources Conflict of interest: None declared

Ethical approval: The study was approved by the Institutional Ethics Committee of GMC Aurangabad, India

\section{REFERENCES}

1. WHO. Media centre Epilepsy. Media Cent Epilepsy [Internet]. 2015;(Fact sheet $\mathrm{N}^{\circ}$ 999):10-3. Available at: http://www.who.int/mediacentre/factsheets/fs999/en/ \#. Accessed 3 June 2016.

2. Lowenstein DH. Section 2 Diseases of the Central Nervous System 445445 Seizures and Epilepsy. In: Harrisons principles of internal medicine; 2015:25422559.

3. Vajda FJE, Eadie MJ. The clinical pharmacology of traditional antiepileptic drugs. Epileptic Disord. 2014;16(4):395-408.

4. Harivenkatesh N, Haribalaji N, David DC, Kumar CM. Therapeutic drug monitoring of antiepileptic 
drugs in a tertiary care hospital in India. Clin Neuropharmacol. 2015;38(1):1-5.

5. McNamara JO. Pharmacotherapy of the Epilepsies. In: Goodman and Gilman's: The Pharmacological Basis of Therapeutics, 12e; 2011:583-606.

6. Tripathi K. Chapter 30 Antiepileptic Drugs. In: Essentials of Medical Pharmacology $7^{\text {th }}$ Edition; 2013:411-424.

7. Blot L, Marcelis A, Devogelaer JP, Manicourt DH. Effects of diclofenac, aceclofenac and meloxicam on the metabolism of proteoglycans and hyaluronan in osteoarthritic human cartilage. $\mathrm{Br} \mathrm{J}$ Pharmacol. 2000;131(7):1413-21.

8. Batlle-Gualda E, Román Ivorra J, Martín-Mola E, Carbonell Abelló J, Linares Ferrando LF, Tornero Molina $\mathrm{J}$, et al. Aceclofenac vs paracetamol in the management of symptomatic osteoarthritis of the knee: a double-blind 6-week randomized controlled trial1, 2. Osteoarthr Cartil. 2007;15(8):900-8.

9. Moon Y, Kang S, Kim T, Lee M. Efficacy and Safety of Aceclofenac Controlled Release in Patients with Knee Osteoarthritis: A 4-week, Multicenter, Randomized, Comparative Clinical Study. Knee Surg Relat Res. 2014;26(1):33-42.

10. Richens A. Clinical Pharmacokinetics of Phenytoin sodium. Clin Pharmacokinet. 1979;4(3):153-69.

11. Neels HM, Sierens AC, Naelaerts K, Scharpé SL, Hatfield GM, Lambert WE. Therapeutic drug monitoring of old and newer anti-epileptic drugs. Clin Chem Lab Med. 2004;42(11):1228-55.

12. Bort R, Ponsoda X, Carrasco E, Mj G, Jv C. Metabolism of aceclofenac in humans. Drug Metab Dispos. 1996;24(8):834-41.

13. Drugs Update. Aceclofenac + Paracetamol information from Drugs Update. Available at: http://www.drugsupdate.com/generic/view/651/Acecl ofenac-+-Paracetamol. Accessed 28 September 2017.

14. Medhi B, Joshi R, Prakash A, Bansal YS, Attrey SD, Singh D, et al. Effect of aceclofenac on pharmacokinetic of Phenytoin sodium. Pak J Pharm Sci. 2012;25(2):295-9.

15. Lancaster GA, Dodd S, Williamson PR. Design and analysis of pilot studies: recommendations for good practice. J Eval Clin Pract. 2004;10(2):307-12.

16. Recipe. Antiepileptics in Serum [Internet]; 2012. Available

at: http://www.recipe.de/en/products_hplc_tdm_15000.h tml. Accessed 23 July 2017.
17. Fromm D. How do non-steroidal anti-inflammatory drugs affect gastric mucosal defenses? Clin Invest Med. Canada; 1987 May;10(3):251-8.

18. Chillistone S, Hardman JG. Factors affecting drug absorption and distribution. Anaesth Intensive Care Med [Internet]. Elsevier Ltd. 2014;15(7):309-13. Available http://dx.doi.org/10.1016/j.mpaic.2014.04.004. Accessed 30 July 2017

19. Sipponen P, Kekki M, Seppala K, Siurala M. The relationships between chronic gastritis and gastric acid secretion. Aliment Pharmacol Ther. England. 1996 Apr;10 Suppl 1:103-18.

20. Sigthorsson G, Tibble J, Hayllar J, Menzies I, Macpherson a, Moots R, et al. Intestinal permeability and inflammation in patients on NSAIDs. Gut. 1998;43(4):506-11.

21. Yanagawa A, Endo T, Kusakari K, Kudo T, Shimada J, Mizushima Y. Endoscopic evaluation of aceclofenac-induced gastroduodenal mucosal damage: a double-blind comparison with sodium diclofenac and placebo. Japa J Rheumatol. 1998 Sep $1 ; 8(3): 249-59$.

22. Hinz B, Rau T, Auge D, Werner U, Ramer R, Rietbrock S, et al. Aceclofenac spares cyclooxygenase 1 as a result of limited but sustained biotransformation to diclofenac. Clin Pharmacol Ther. 2003;74(3):22235 .

23. Sansom LN, Evans AM. What is the True Clinical Significance of Plasma Protein Binding Displacement Interactions? Drug Saf. 1995;12(4):227-33.

24. Nation RL, Evans AM, Milne RW. Pharmacokinetic drug interactions with Phenytoin sodium (Part I). Clin Pharmacokinet. 1990;18(1):37-60.

25. Aronson JK, Hardman M, Reynolds DJM. ABC of Monitoring Drug Therapy Phenytoin sodium. Br Med J. 1992;305(6863):1215 LP-18.

26. Barry M, Feely J. Enzyme induction and inhibition. Pharmacol Ther. 1990;48(1):71-94.

Cite this article as: Kulkarni RS, Chandaliya KC. Effect of aceclofenac on pharmacokinetics of phenytoin sodium in epileptic patients. Int J Basic Clin Pharmacol 2018;7:1912-6. 